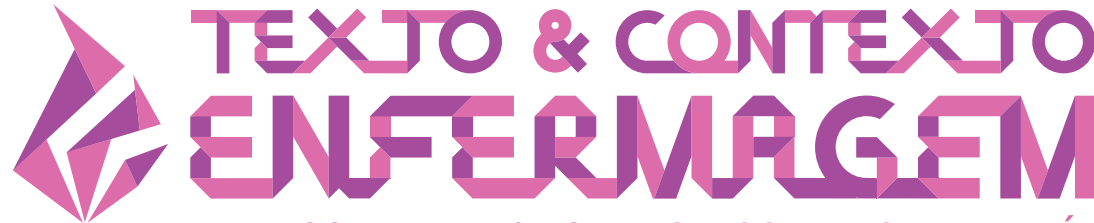

TEXT \& CONTEXT NURSING TEXTO \& CONTEXTO ENFERMERÍA

\section{HAZARDOUS DRINKING AND ITS \\ CORRELATES AMONG UNIVERSITY STUDENTS IN BARBADOS}

\section{Laura Seale-Foster ${ }^{1}$ (i) Marya Hynes $^{2}$}

${ }^{1}$ National Council on Substance Abuse. St. Michael, Barbados. ${ }^{2}$ Comisión Interamericana para el Control del Abuso de Drogas, Observatório Interamericano de Drogas. Washington, DC, Estados Unidos.

\begin{abstract}
Objective: this study investigates the relationship between problematic drinking, gender, age, marijuana consumption, driving under the influence of alcohol and riding with an alcohol intoxicated driver among university students in Barbados.

Method: a cross-sectional survey was used to collect data from 371 students, the majority of whom were female $(73.6 \%)$ and between the ages of 18 and $21(60.6 \%)$.

Results: the majority of participants $(81.1 \%)$ consumed alcohol in the preceding 12 months and $17.2 \%$ met the criteria for problematic drinking based on their Alcohol Use Disorders Identification Test score. A significant relationship was uncovered between problematic drinking and student gender, driving under the influence alcohol, riding with an alcohol intoxicated driver and marijuana consumption.

Conclusion: further research using a representative sample should be conducted to determine if the findings hold true for the wider student population. Nevertheless, the study highlights the presence of problematic drinking among the students and therefore initiatives should be implemented to reduce and eliminate its occurrence.
\end{abstract}

DESCRIPTORS: Drinking. Risk-taking behaviour. University students. Drugs. Illicit drugs. Alcohol. Marijuana. 


\section{BEBIDAS PERIGOSAS E SEUS CORRELATOS ENTRE UNIVERSITÁRIOS DE BARBADOS}

\section{RESUMO}

Objetivo: este estudo investiga a relação entre o uso problemático de bebidas, sexo, idade, consumo de maconha, dirigir sob a influência de álcool e andar com motorista alcoolizado entre estudantes universitários em Barbados.

Método: utilizou-se um levantamento transversal para coleta de dados de 371 estudantes, sendo a maioria do sexo feminino (73,6\%) e com idade entre 18 e 21 anos $(60,6 \%)$.

Resultados: a maioria dos participantes $(81,1 \%)$ consumiu álcool nos últimos 12 meses e 17,2\% preencheram os critérios para uso problemático de bebidas com base na pontuação do Teste de Identificação dos Distúrbios do Uso de Álcool. Uma relação significativa foi descoberta entre o uso problemático bebidas e o gênero dos estudantes, dirigir sob a influência do álcool, andar com um motorista alcoolizado e consumir maconha.

Conclusão: mais pesquisas usando uma amostra representativa devem ser conduzidas para determinar se as descobertas são verdadeiras para a população estudantil mais abrangente. No entanto, o estudo destaca a presença de consumo de bebidas problemático entre os alunos e, portanto, iniciativas devem ser implementadas para reduzir e eliminar sua ocorrência.

DESCRITORES: Beber. Comportamento de tomada de risco. Universitários. Drogas. Drogas ilícitas. Álcool. Maconha.

\section{BEBIDAS PELIGROSAS Y SUS CORRELATOS ENTRE UNIVERSITARIOS DE BARBADOS}

\section{RESUMEN}

Objetivo: este estudio investiga la relación entre el uso problemático de bebidas, sexo, edad, consumo de marihuana, conducir bajo los efectos del alcohol y conducir con un conductor ebrio entre estudiantes universitarios en Barbados.

Método: se utilizó una encuesta transversal para recopilar los datos de 371 estudiantes, la mayoría de ellos mujeres $(73,6 \%)$ y edades entre 18 y 21 años $(60,6 \%)$.

Resultados: la mayoría de los participantes (81.1\%) consumió alcohol en los últimos 12 meses y 17,2\% cumplió con los criterios para el uso problemático de bebidas, según el puntaje del Test de Identificación de Trastornos por Consumo de Alcohol. Se descubrió una relación significativa entre el consumo problemático de bebidas y el género de los estudiantes, conducir bajo los efectos del alcohol, conducir con un conductor ebrio y consumir marihuana.

Conclusión: se debe realizar una investigación adicional con una muestra representativa para determinar si los hallazgos son ciertos para la población estudiantil en general. Sin embargo, el estudio destaca la presencia del consumo problemático de bebidas entre estudiantes y, por lo tanto, se deben implementar iniciativas para reducir y eliminar su ocurrencia.

DESCRIPTORES: Beber. Conducta de toma de riesgos. Universitarios. Drogas. Drogas ilícitas. Alcohol. Marihuana. 


\section{INTRODUCTION}

Hazardous drinking, sometimes referred to as problem drinking, is a public health issue and is particularly concerning given its associated harms and the popularity of alcohol consumption worldwide. Throughout this hemisphere, alcohol continues to be the most frequently consumed substance ${ }^{1}$ and Barbados is no exception, with approximately $75 \%$ of this country's general and secondary school populations reporting lifetime alcohol use..$^{2-3}$ Local past year prevalence rates for these populations stand at around $55 \%{ }^{2-3}$ Alcohol use is also common among university and college students on the island. One local study found that $70.6 \%$ of students at tertiary level institutions (university, colleges and post-secondary schools) consumed low alcohol content beverages (beer, stout, etc.) to varying degrees. ${ }^{4}$ Medium (wine, liqueurs, etc.) and high (rum, vodka, brandy, etc.) alcohol content beverages were consumed by $65.1 \%$ and $54.1 \%$ of students respectively. ${ }^{4}$

The international literature highlights the issue of hazardous alcohol use among university students across the globe. One study found high rates of alcohol use disorders and hazardous drinking among undergraduate students from seven universities across England. ${ }^{5}$ Three-fifths of the sample scored eight or above on the Alcohol Use Disorders Identification Test (AUDIT), thus testing positive for hazardous drinking. There were no significant differences between the AUDIT scores of males and females.

The AUDIT was also used to investigate alcohol consumption among university students in Malawi. ${ }^{6}$ Just under half of the participants $(45.3 \%)$ in that study were considered problem drinkers as they received an AUDIT score of eight or above. Additionally, the researchers found a statistically significant difference in the AUDIT scores of males and females, with more males being classified as problem drinkers. ${ }^{6}$ Research conducted among Vietnamese medical students also found that males were more likely than females to be classified as problem drinkers. ${ }^{7}$ While $12.5 \%$ of participating medical students had an AUDIT score of eight or more, males were 14.3 times more likely than females to receive such a score. ${ }^{7}$

Hazardous drinking has been associated with other dangerous behaviours. For instance, research conducted among Irish university students found that hazardous drinkers were more likely to smoke, use illicit drugs and engage in increased sexual activity. ${ }^{8-9}$

Hazardous drinking has also been linked to driving under the influence (DUI) of alcohol. One group of researchers found the mean AUDIT score for drivers convicted of DUI alcohol to be greater than eight $(M=11.1, S D=5.9)$, indicating hazardous use, while the mean score for those without such a conviction was less than eight $(M=7.4, S D=5.4) .{ }^{10}$ Similarly, in another study, AUDIT scores were found to increase as the number of DUI convictions a person received increased. ${ }^{11}$ Persons with one conviction had a mean score of less than eight while persons with two or more convictions had a mean score greater than eight, suggestive of hazardous use. ${ }^{11}$

Hazardous alcohol use, as measured by the AUDIT, has also been identified as a risk factor for riding in a car operated by an alcohol intoxicated driver. ${ }^{12}$ Correspondingly, binge drinking, an indicator for hazardous alcohol use, has also been proven to be a predictor of riding with an alcohol impaired driver. ${ }^{13}$

The issue of hazardous alcohol use and its association with DUI behaviours is of particular concern among university students, as young adults are the most at-risk group for DUI. ${ }^{14}$ Furthermore, motor vehicle accidents have been identified as the leading cause of death among persons ages 15 to 29 in Latin America and the Caribbean. ${ }^{15}$

The aim of this study was to assess the hazardous use of alcohol among university students in Barbados and to determine its correlates. More specifically, the study sought to determine if hazardous alcohol use is related to gender, age, consumption of marijuana, consumption of marijuana 
and alcohol in one session (combined), DUI alcohol and being a passenger in a car operated by an alcohol intoxicated driver.

\section{METHOD}

This quantitative study was cross-sectional in design and utilized the survey method for data collection. The study's population was limited to undergraduate and post-graduate students, ages 18 to 29 , enrolled in on-campus programmes at a university in Barbados. An online sample size calculator identified the minimum required sample size as 368 .

A non-probability sample of 371 students was selected from within the classrooms of the university. To facilitate this process, lecturers were contacted and asked if they would be willing to have the questionnaire administered during their class time. A mutually convenient date and time for questionnaire distribution was established with those lecturers who consented.

Once in the classroom, potential participants were identified and provided (as a group) with a verbal description of the study. Those who agreed to participate were required to sign consent forms and were then provided with a copy of the questionnaire to complete immediately. This process took approximately 20 minutes. Students placed completed questionnaires in the envelope(s) provided as they exited the room.

A self-administered questionnaire was used to collect the data for this study. Participants were asked to provide their age and gender. In addition, they were asked about their past year use of alcohol, marijuana and alcohol and marijuana combined.

Persons who consumed alcohol in the preceding year were asked to complete the AUDIT to determine if they were hazardous drinkers. This 10-item scale was developed by the World Health Organization and identifies hazardous and harmful drinking patterns during the preceding 12 month period. It has high internal consistency and test-retest scores and correlates strongly with other measures used to evaluate hazardous alcohol consumption. ${ }^{16}$ Responses to each item are assigned a numerical score. Item scores are summed to provide a total score for interpretation. In accordance with interpretation instructions, persons receiving a score of eight or above were considered to have met the criteria for hazardous alcohol use and were therefore classified as "hazardous drinkers". Those with scores of 7 or below were considered to be "non-hazardous drinkers".

Past year alcohol users were also asked to indicate the number of times they had driven, or had been a passenger in a car driven by someone, under the influence of alcohol in the preceding 12 months. Possible responses included "Never", "Once", "2 times", and up to "8 or more times". For the purposes of analysis, the responses to these items were recoded into "Yes/No".

The data for this study was collected as part of a wider research project which examined DUI among university students. As such, the questionnaire included additional items which evaluated hazardous marijuana use, DUI marijuana, DUI marijuana and alcohol combined, DUI within participants' social networks and the perception of risk associated with DUI.

Data analysis was carried out using the Statistical Package for the Social Sciences (SPSS) version 21. Descriptive statistics were used to determine the sample's demographic characteristics and the proportionate use of alcohol within the sample. Chi-square analyses and cross-tabulations were used to evaluate the relationship between AUDIT classification (hazardous/non-hazardous drinker) and participant age and gender. Chi-square analyses and cross-tabulations were also used to investigate the relationship between AUDIT classification and DUI alcohol in the past year, being a passenger with a driver who has been using alcohol in the past year, past year marijuana use and the combined use of alcohol and marijuana in the past year. 


\section{RESULTS}

\section{Sample demographics}

Females accounted for $73.6 \%$ of the sample and males $26.4 \%$. This a reflection of the sex ratio of students enrolled at the university. The majority of participants $(60.6 \%)$ were in the 18 to 21 age group while fewer persons were in the 22-25 (31.0\%) and 26-29 (8.4\%) age categories.

\section{Alcohol consumption \& hazardous drinking}

Most $(81.1 \%)$ participants $(80.6 \%$ of males and $81.3 \%$ of females) had consumed alcohol during the 12 months leading up to the survey. The mean AUDIT score was 4.4073 , with a minimum of 0 and a maximum of 22. Based on their AUDIT scores, $17.2 \%$ of these persons met the criteria for hazardous drinking while $82.8 \%$ were non-hazardous.

\section{Hazardous alcohol use \& sample demographics}

Participant gender was related to AUDIT classification ( $d . f .=1, c^{2}=8.481, p<.05$ ). The percentage of males categorized as hazardous drinkers was greater than the percentage females receiving this classification (See Table 1). With regards to age, no relationship was found between this variable and AUDIT classification (See Table 1).

Table 1 - Cross-tabulations of Alcohol Use Disorders Identification Test Classification and participant age and sex. Barbados, 2016

\begin{tabular}{lccc}
\hline & Hazardous drinker & Non-hazardous drinker & \multirow{2}{*}{$\chi^{2}$} \\
\cline { 2 - 3 } & $\%$ & $\%$ & \multirow{2}{*}{$8.481^{*}$} \\
Sex & & & \\
Male & 27.8 & 72.2 & \multirow{2}{*}{3.179} \\
Female & 13.5 & 86.5 & \\
Age category & & & \\
$18-21$ & 19.4 & 80.6 & \\
$22-25$ & 16.0 & 84.0 & \\
$26-29$ & 4.5 & 95.5 & \\
\hline
\end{tabular}

${ }^{*} \mathrm{p}<.05 ; \uparrow$ Data only for users of alcohol

\section{Hazardous alcohol use \& driving under the influence of alcohol}

Chi-square analysis revealed an association between AUDIT classification and DUI alcohol (d.f. $\left.=1, c^{2}=14.286, p<.001\right)$. Approximately three quarters $(76.3 \%)$ of hazardous drinkers reported DUI alcohol at least once during the preceding 12 months. In contrast, only $41.4 \%$ of non-hazardous drinkers admitted doing so during the same time period.

AUDIT classification was also related to riding in a car operated by someone under the influence of alcohol during the past year (d.f. $=1, c^{2}=5.008, p<.05$ ). While $80.8 \%$ of hazardous drinkers reported engaging in this behaviour, only $64.8 \%$ of non-hazardous drinkers reported doing so (Table 2 ). 
Table 2 - Cross-tabulations of Alcohol Use Disorders Identification Test classification and alcohol intoxicated driving behaviours. Barbados, 2016

\begin{tabular}{|c|c|c|c|c|c|c|}
\hline \multirow{2}{*}{$\begin{array}{l}\text { Alcohol Use Disorders } \\
\text { Identification Test } \\
\text { classification* }\end{array}$} & \multicolumn{2}{|c|}{$\begin{array}{l}\text { Driving under the influence } \\
\text { Alcohol in past year }\end{array}$} & \multirow[t]{2}{*}{$\chi^{2}$} & \multicolumn{2}{|c|}{$\begin{array}{c}\text { Passenger with driving } \\
\text { under the influence alcohol } \\
\text { driver in past year }\end{array}$} & \multirow[t]{2}{*}{$\chi^{2}$} \\
\hline & No(\%) & Yes(\%) & & No(\%) & Yes(\%) & \\
\hline Non-hazardous drinker & 58.6 & 41.4 & $14.286 \dagger$ & 35.2 & 64.8 & $5.008^{*}$ \\
\hline Hazardous drinker & 23.7 & 76.3 & & 19.2 & 80.8 & \\
\hline
\end{tabular}

${ }^{*} \mathrm{p}<.05 ; \mathrm{t} p<.001$; Data only for users of alcohol

\section{Hazardous alcohol use \& marijuana use}

There was an association between AUDIT classification and past year marijuana use (d.f.=1, $\left.c^{2}=20.516, p<.001\right)$. The proportion of hazardous drinkers who used marijuana in the preceding 12 months was greater than the proportion of non-hazardous drinkers who had done so (Table 3). Likewise, the use of marijuana and alcohol in the same sitting (combined) during the past year was more common among hazardous drinkers (d.f. $\left.\left.=1, c^{2}=32.172\right), p<.001\right)$ (Table 3 ).

Table 3 - Cross-tabulations of Alcohol Use Disorders Identification Test Classification and marijuana use. Barbados, 2016

\begin{tabular}{|c|c|c|c|c|c|c|}
\hline \multirow{2}{*}{$\begin{array}{l}\text { Alcohol Use Disorders } \\
\text { Identification Test } \\
\text { classification* }\end{array}$} & \multicolumn{2}{|c|}{$\begin{array}{l}\text { Marijuana use } \\
\text { in past year }\end{array}$} & \multirow[t]{2}{*}{$\chi^{2}$} & \multicolumn{2}{|c|}{$\begin{array}{c}\text { Combined alcohol \& } \\
\text { marijuana use in past year }\end{array}$} & \multirow[t]{2}{*}{$\chi^{2}$} \\
\hline & No(\%) & Yes(\%) & & No(\%) & Yes(\%) & \\
\hline Non-hazardous drinker & 77.2 & 22.8 & 20.516† & 90.4 & 9.6 & $32.172 \dagger$ \\
\hline Hazardous Drinker & 46.2 & 53.8 & & 59.6 & 40.4 & \\
\hline
\end{tabular}

${ }^{*}$ Data only for users of alcohol ; $\nmid p<.001$

\section{DISCUSSION}

The past year prevalence rate for alcohol use was higher than that uncovered by previous local research $(+\sim 25 \%)$. This is not surprising as the previous research which generated prevalence rates focused on the general and secondary school populations. University students on the other hand, typically have higher rates of alcohol consumption which may be due in part to the social environment on campus, the ease with which alcohol can be obtained and increased autonomy from parents. ${ }^{17-19}$ In addition, there is also evidence which suggests that undergraduate students drink even more than their non-student peers..$^{5,17}$

The level of hazardous alcohol use within the sample is not alarmingly high when compared to that of international studies. On the contrary, it is notably lower than that uncovered in countries such as the United Kingdom and Malawi. ${ }^{5-6}$ Nevertheless, it highlights the fact that hazardous alcohol use exists among university students in Barbados, and therefore targeted interventions aimed at preventing and addressing this phenomenon should be developed and implemented. However, further research should first be conducted to ensure a full understanding of the issue and, by extension, guide their development.

The study also found that hazardous drinking among university students in Barbados is associated with gender and other risky behaviours such as DUI alcohol, riding with an alcohol intoxicated driver and using marijuana, both alone and in combination with alcohol. These findings 
correspond with the international literature. Age was the only variable under investigation which was not related to hazardous drinking.

The fact that male students were more likely to be hazardous drinkers may be a byproduct of socialization as society is generally more accepting of such behaviour among males. ${ }^{6}$ Associated behaviours, for example, excessive alcohol consumption and binge drinking, are often considered as signs of masculinity. ${ }^{9}$ As such, young males are more likely to adopt these behaviours in an attempt to prove their machismo and maturity. Additionally, it is thought that males are greater risk takers than females ${ }^{20}$ and thus are more likely to engage in risky behaviours such as hazardous drinking. It is important to note that the presence of such gender differences may have important implications for selective and indicated prevention interventions, and should therefore be considered when such efforts are being designed and implemented.

The finding that hazardous drinking is related to DUI alcohol, riding with an alcohol intoxicated driver and marijuana use coincides with research which has shown an association between higher AUDIT scores and risk taking behaviour. ${ }^{17}$ Similarly, the findings are also consistent with research which has found a relationship between alcohol consumption patterns, particularly high rates of use and dependence, and behavioural risk taking. ${ }^{21-22}$ It is possible that hazardous alcohol consumption increases the risk for participating in other risky behaviours, due in part to the mere effects of intoxication. ${ }^{17,23}$

The study relied on the use of a non-probability sampling method. This prevents the generalization of the findings to the wider university population as the sample was not representative. Furthermore, certain subject areas (e.g. psychology, social work) were overrepresented within the sample due to many lecturers' unwillingness to facilitate the data collection process. This may have affected the results; however, it is not possible to determine if non-respondents from other subject areas may have differed in their responses.

The social desirability bias may have resulted in persons underreporting their drug use and DUI behaviours. Thus, the findings may not be an accurate reflection of what is happening within the target population. However, it is hoped that the anonymity afforded by the study, coupled with the guarantee of confidentiality, counteracted any potential impact which the social desirability bias may have had.

Similarly, the accuracy of participants' responses, and by extension the study's findings, may have inadvertently been reduced by the reliance on self-report data, as participants may have been unable to accurately recall the events under study.

\section{CONCLUSION}

This study provides insight into alcohol consumption by university students in Barbados and highlights the existence of hazardous drinking among the student body. It also reveals a number of risk taking behaviours which are associated with hazardous drinking. This information can be used to inform university policies as well as to guide the design and implementation of programmes and initiatives aimed at discouraging risky drinking practices, reducing high risk behaviours and promoting healthy lifestyles. In so doing, it must be remembered that universities do not exist in a vacuum but are part of the wider communities, cities and countries in which they are located. As such, any efforts should be multifaceted and should involve relevant organizations and businesses, including bars and nightclubs, as well as other government agencies and departments, for example the police, health services, the local drug council, etc. so as to increase their success.

As a consequence of this study's limitations, it is recommended that further research using a probability sample be conducted to determine if the findings hold true for the wider student body. In addition, quantitative research on the topic can be complemented by qualitative studies of a similar nature which can provide useful context and a greater understanding of the problem. 


\section{REFERENCES}

1. Inter-American Drug Abuse Control Commission. Report on drug use in the Americas 2015. Washington(US): OEA; 2015.

2. National Council on Substance Abuse. Barbados national household survey 2006. Barbados: NCSA; 2007.

3. National Council on Substance Abuse. Barbados secondary school survey 2013. Barbados: NCSA; 2014.

4. National Council on Substance Abuse. Survey of drug use and risky sexual behaviour in tertiary institutions in Barbados. Barbados: NCSA; 2007.

5. Heather N, Partington S, Partington E, Longstaff F, Allsop S, Jankowski M, et al. Alcohol use disorders and hazardous drinking among undergraduates at English Universities. Alcohol and Alcoholism [Internet]. 2011 [cited 2017 May 15];46(3):270-7. Available from: https://academic. oup.com/alcalc/article/46/3/270/240284/Alcohol-Use-Disorders-and-Hazardous-Drinking-among

6. Zverev Y. Problem drinking among university students in Malawi. Coll. Antropol [Internet] 2008 [cited 2017 May 12];32(1):27-31. Available from: https://www.researchgate.net/publication/5356556_ Problem_drinking_among_university_students_in_Malawi

7. Diep P. Alcohol consumption among students in Vietnam. Netherlands: Gildeprint; 2016.

8. Davoren M, Shiely F, Byrne M, Perry I. Hazardous alcohol consumption among university students in Ireland: A cross-sectional study. BMJ Open. 2015 [cited 2017 May 12];5:e006045. Available from: https://dx.doi.org/10.1136/bmjopen-2014-006045

9. Hope A, Dring C, Dring J. College lifestyle and attitudinal national (CLAN) survey: The health of Irish students. Dublin (IE): Health Service Executive; 2005 [cited 2017 May 9]. Available from: http://www.drugsandalcohol.ie/4327/1/2670-2853.pdf

10. Jia K, King M, Sheehan M, Fleiter J, Ma W, Zhang J. Baseline study of alcohol dependence among general drivers and drink driving offenders in Guangzhou, China. Paper presented at Australasian Road Safety Research Policing Education Conference 2013. Brisbane(AU): Queensland University of Technology; 2013 [cited 2017 May 8]. Available from: http://acrs.org. au/files/arsrpe/Paper\%20187\%20-\%20Jia\%20-\%20Alcohol\%20and\%20Driving.pdf

11. Webster M, Leukefeld C, Clark D, Cook S, Muralidharan L. Kentucky DUI assessment for 2004. Lexington, Kentucky (US): University of Kentucky Center on Drug and Alcohol Research; 2005 [cited 2017 May 8]. Available from: http://cdar.uky.edu/downloads/dui2004reportfinal.pdf

12. Cartwright J, Asbridge M. Passengers' decisions to ride with a driver under the influence of either alcohol or cannabis. J Stud Alcohol Drugs [Internet]. 2011 [cited 2017 May 9] Jan;72(1):86-96. Available from: https://www.ncbi.nlm.nih.gov/pubmed/21138715

13. Van Beurden E, Zask A, Brooks L, Dight R. Heavy episodic drinking and sensation seeking in adolescents as predictors of harmful driving and celebrating behaviours: Implications for prevention. J Adolesc Health [Internet]. 2005 July [cited 2017 May 15];37(1):37-43. Available from: http:// rrisk.com.au/wp-content/uploads/2013/05/RRISK-journal-article-HED-and-sensation-seeking.pdf

14. Young adults remain most at-risk group for DUI despite downward trend. Oklahoma: Brandlnsight; 2016 Jan 24 [cited 2017 May 11]. Available from: http://newsok.com/article/5474143

15. World Health Organization. Road traffic injuries. Geneva $(\mathrm{CH})$ : World Health Organization; 2015 [cited 2017 May 2]. Available from: http://www.who.int/mediacentre/factsheets/fs358/en/

16. Babor T, Higgins-Biddle J, Saunders J, Monteiro M. The alcohol use disorders identification test: Guidelines for use in primary care. 2nd ed. Geneva (CH): World Health Organization; 2001. 
17. O'Neill G, Martin N, Birch J, Oldham A, Newbury-Birch D. The drinkers degree: Risk taking behaviours amongst undergraduate student drinkers. J Addiction [Internet]. 2015 [cited 2017 May 2]; 2015: Available from: https://www.hindawi.com/journals/jad/2015/965438/

18. Suerken C, Reboussin B, Sutfin E, Wagoner K, Spangler J, Wolfson M. Prevalence of marijuana use at college entry and risk factors for initiation during freshman year. Addict Behav [Internet]. 2014 [cited 2017 May 1];39(1):302-7. Available from: https://www.ncbi.nlm.nih.gov/pmc/articles/ PMC4098711/

19. Mitchell C, Simich L, Strike C, Brands B, Giesbrecht N, Khenti A. Exploration of simultaneous polydrug use: risk and protective factors in undergraduate students in one university, Kingston - Jamaica. Texto Contexto Enferm [Internet]. 2012 [cited 2017 Aug 31];21(spe):68-73. Available from: http://www.scielo.br/scielo.php?script=sci_arttext\&pid=S0104-07072012000500009\&lng=en

20. Jules M, Noh S, Hamilton H, Brands B, Gastaldo D, Wright M, Cumsille F, Khenti A. Spirituality, gender, and drug use among students from one university in Barbados. Texto Contexto Enferm [Internet]. 2015 [cited 2018 August 10];24(Esp.):117-24. Available from: http://www.scielo.br/pdf/ tce/v24nspe/0104-0707-tce-24-spe-00117.pdf

21. Dumbili E. Changing patterns of alcohol consumption in Nigeria: An exploration of responsible factors and consequences. Je BSA Medsoc Group [Internet]. 2013 [cited 2017 April 27];7(1):2033. Available from: http://www.medicalsociologyonline.org/resources/Vol7lss1/7.1-ChangingPatterns_Dumbilli.pdf

22. Ekpenyong N, Aakpege N. Alcohol consumption pattern and risky behaviour: A study of University of Port Harcourt. J Human Soc Science [Internet]. 2014 Mar [cited 2017 April 27];19(3):25-32. Available from: http://www.iosrjournals.org/iosr-jhss/papers/Vol19-issue3/Version-1/E019312532.pdf

23. Wechsler $\mathrm{H}$, Lee J, Kuo M, Seibring $M$, Nelson $T$, Lee $H$. Trends in college binge drinking during a period of increased prevention efforts: Findings from 4 Harvard School of Public Health College alcohol study surveys, 1993-2001. J Am College Health [Internet]. 2002 [cited 2017 Apr 26];50:203-17. Available from: https://www.ncbi.nlm.nih.gov/pubmed/11990979 


\section{NOTES}

\section{CONTRIBUTION OF AUTHORITY}

Study design: Seale-Foster L, Hynes M.

Data collect: Seale-Foster $L$.

Data analysis and interpretation: Seale-Foster L, Hynes M.

Discussion of the results: Seale-Foster L, Hynes M.

Writing and / or critical review of content: Seale-Foster L, Hynes M.

Review and final approval of the final version: Seale-Foster $L$.

\section{ETHICS COMMITTEE IN RESEARCH}

Ethical approval was sought and granted by the Centre of Addiction and Mental Health Research Ethics Board, Toronto, Canada.

\section{CONFLICT OF INTEREST}

There is no conflict of interest.

\section{HISTORICAL}

Received: September 25, 2018.

Approved: May 20, 2019.

\section{CORRESPONDENCE AUTHOR}

Laura Seale-Foster

Iseale@ncsa.org.bb 